\title{
The Use of the Community Diffusion Model to Develop Community Partnerships and Overcome Barriers to an Urban College Internship Program
}

\author{
R. Eric Weston and Catherine D. Stayton \\ Community Intern Partnership of the Department of Health and Community Services \\ Brooklyn College of the City University of New York
}

\begin{abstract}
The current scarcity of employment opportunities has increased the importance of the internship experience for graduating college students. However, the development of internship sites is fraught with both internal and external barriers. The goal of this article is to describe the development of an internship program in an urban-based liberal arts college. The article describes the: a) use of the Community Diffusion Model to develop partnerships with community sites, b) multilevel barriers to successful program development and maintenance, and c) strategies used to overcome the barriers. During a threeyear period, 110 students participated in the internship program, 59 undergraduates and 51 graduates. Both graduate and undergraduate students were predominantly female, aged $21-45$. A total of 60 internship positions based in 31 community partner agencies have been developed. Student participation was highest in the direct service activities, and lowest in education activities. Organizational, individual, task-related, and relationship barriers affected the development and maintenance of partnerships. Organizational barriers proved to be the most difficult of these barriers to resolve satisfactorily, while task related barriers proved the most manageable. Establishing partnerships among stakeholders while anticipating multiple implementation barriers was the important lesson learned. Based upon our experiences, we offer recommendations for the development and maintenance of internship programs to colleges, community institutions/organizations, site and program directors, and policy makers.
\end{abstract}

(C) 2004 Californian Journal of Health Promotion. All rights reserved.

Keywords: Internships, community partnerships, barriers, Community Diffusion Model

\section{Introduction}

Shrinking employment opportunities has elevated the importance of direct work experience for all stakeholders in the educationto- workforce transition: students seek skills to increase their marketability, Human Resource Administrators search for graduates with specific workplace skills, while colleges and universities utilize learning in the field as a recruitment tool (Allegretto \& Stettner, 2004; Anderson, Pulich, \& Sisak, 2002; Ryan, Toohey, \& Hughes, 1996). The relevance of direct work experience is particularly evident in rapidly changing fields such as community and public health (Hibbert, 2003).

The traditional vehicle to gain real-world experience while obtaining a college degree is the internship experience (Coombs, 1998). Through well-planned and implemented programs, the goals of the student, college administrators, and human resource professional are fulfilled. However, developing successful practicum opportunities requires collaboration and coordination among the stakeholders. Unfortunately, competing needs among these stakeholders present numerous barriers to success.

The goal of this article is to describe the development of the Community-based Health Internship Programs for undergraduate and graduate students in an urban, liberal arts college. Specifically, the article will describe the: a) theoretical framework guiding the development and maintenance of internship 
sites, b) process of developing relationships with potential community partners, and c) the barriers encountered throughout the process. Additionally, case scenarios are provided to illustrate both theory and practice issues.

\section{Program Overview}

Graduate. The field experience in the graduate programs, i.e., M.P.H. and M.A., allows students to expand their understanding of organizations involved public health activities ranging from research to health education advocacy. Students spend a minimum of 60 hours at an approved site. Additionally, the students attend a weekly seminar at the college during which salient topics are discussed, such as community health needs assessment. (see PowerPoint Presentation 1). The Faculty Internship Director (FID) and the Field Supervisor (FS) jointly assign grades, based upon student performance in the field and in the classroom.

Undergraduate. The structure of the undergraduate program, i.e., BA and BS, follows that of the graduate program with a major exception. Undergraduate students are required to provide 90 hours of fieldwork for satisfactory completion (see PowerPoint Presentation 2).

\section{Theoretical Perspective}

Two overarching premises guided the development of both undergraduate and graduate Internship program's goals. First, the relationship among the students, the college and the sites must be mutually beneficial to all stakeholders. The shared objectives included the following: a) community partners would receive interns to contribute to specified projects/ products, participate in the training of fledging professionals, and identify candidates for future positions in their workforce; b) students would develop marketable skills, earn college credits, and integrate theory into practice; c) the FID would mentor student interns through the fieldwork experience and develop partnerships in the community; and d) the college would establish itself as a good community citizen, gain social capital, and provide meaningful educational experiences to the students. Second, the project would experience multiple barriers, operating at multiple levels, throughout each stage of development and operation. The ability to effectively deal with each level of barriers would determine the effectiveness and longevity of the program.

Two theoretical frameworks helped to operationalize these premises, the Community Diffusion Model and the model of multilevel interactions. Each of these frameworks is described in detail below.

Community Diffusion Model (CDM). The CDM, an established community-based framework, provides a roadmap for integrating the interests of multiple stakeholders. Developed by the National Heart, Lung, and Blood Institute (NHLBI) as a method of disseminating health related information to communities of color, the basic principles of the CDM are essential for the success of any program that operates within a community framework (NHLBI, 1987). A key element in this model is a respect for the cultural mores and community norms of the target community, a critical ingredient for institutions seeking to collaborate with community partners, such as community-based organizations or health care and educational institutions (Weston, Rapkin, Potts, Smith, 1998; Weston et al., 1992). Including the community partners as equals in all aspects of the process, i.e., planning, implementation, and evaluation, operationalizes this respect (Bowman, 1991). The nine steps that comprise the CDM approach to communitybased health efforts can be found in Table 1 .

Expectations of stakeholders' interactions were framed by a social ecological perspective, which suggests that context conditions relationships (Stokols, 1992). Each stakeholder is simultaneously a potential facilitator or barrier to successful program development. Meichenbaum and Turk (1987), warn that multiple barriers must be anticipated, including: a) organizational barriers, rooted in institutional policy; b) task-related barriers, rooted in the project workplan; c) individual barriers, rooted in individual behaviors that interfere with program goals; and, d) relationship barriers, rooted in the interaction of individuals with diverse backgrounds, beliefs, values and 
behavioral repertoires. These complex multilevel interactions are illustrated in Table 2.

Table 1

Steps of the CDM Model of Multilevel Interactions

\begin{tabular}{|ll|l|}
\hline \multicolumn{2}{|c|}{ Step } & \multicolumn{1}{|c|}{ Description } \\
\hline $\begin{array}{l}\text { 1. } \\
\text { Establish a working group of } \\
\text { co-change agents. }\end{array}$ & $\begin{array}{l}\text { Recognize the importance of respecting the community } \\
\text { partners' autonomy }\end{array}$ \\
\hline $\begin{array}{l}\text { 2. } \\
\text { 3. }\end{array}$ & $\begin{array}{l}\text { Assess the community } \\
\text { problem is often multi-directional. Thus, it is most effective } \\
\text { when co-change agents share their views of the target issue }\end{array}$ \\
\hline 4. $\quad$ Determine measurable goals & $\begin{array}{l}\text { Implement a thorough community analysis that includes } \\
\text { cultural, economic, educational, health, religious, social- } \\
\text { demographic factors, and vocational issues }\end{array}$ \\
\hline 5. Plan diffusion activities. & $\begin{array}{l}\text { Establish the indices by which the success of the campaign } \\
\text { can be evaluated }\end{array}$ \\
\hline 6. Prepare communication tools & $\begin{array}{l}\text { Adopt flexible implementation plans that can be changed } \\
\text { contingent upon events in the field }\end{array}$ \\
\hline 7. $\quad$ Pretest & $\begin{array}{l}\text { Develop communication tools targeted towards specific } \\
\text { populations }\end{array}$ \\
\hline 8. $\quad$ Implement and monitor the plan & Conduct trial runs of the project prior to full implementation \\
\hline & & $\begin{array}{l}\text { Utilize a continuous feedback loop during the program } \\
\text { implementation phase. These activities allow program staff } \\
\text { to make modifications as necessary }\end{array}$ \\
\hline 9. $\quad$ Assess the final results & Evaluate the results of the initiative to guide future efforts \\
\hline
\end{tabular}

Table 2

Multidimensional Barriers to Success

\begin{tabular}{|l|l|l|l|l|l|l|}
\hline \multicolumn{1}{|c|}{ Barrier } & \multicolumn{1}{|c|}{ Category } \\
\hline & \multicolumn{1}{|c|}{ A } & \multicolumn{1}{c|}{ B } & \multicolumn{1}{c|}{ C } & \multicolumn{1}{c|}{ D } & \multicolumn{1}{c|}{ E } & \\
\hline Organizational & $\begin{array}{l}\text { Community } \\
\text { Partners }\end{array}$ & College & & & \\
\hline Individuals & Students & $\begin{array}{l}\text { Clients/ } \\
\text { Participants }\end{array}$ & Staff & $\begin{array}{l}\text { Site } \\
\text { Administrator }\end{array}$ & $\begin{array}{l}\text { Internship } \\
\text { Program } \\
\text { Director }\end{array}$ & \\
\hline Task Related & $\begin{array}{l}\text { Job } \\
\text { description }\end{array}$ & $\begin{array}{l}\text { Target } \\
\text { population }\end{array}$ & & & & \\
\hline Relationship & $\begin{array}{l}\text { Internship } \\
\text { Director- } \\
\text { Site Director }\end{array}$ & $\begin{array}{l}\text { Internship } \\
\text { Director - } \\
\text { Student }\end{array}$ & $\begin{array}{l}\text { Site } \\
\text { Director - } \\
\text { Student }\end{array}$ & $\begin{array}{l}\text { Student - } \\
\text { Client }\end{array}$ & $\begin{array}{l}\text { College - } \\
\text { Community } \\
\text { Partners }\end{array}$ & $\begin{array}{l}\text { Site } \\
\text { staff }\end{array}$ \\
\hline
\end{tabular}




\section{Results}

Sociodemographic data for both the undergraduate and graduate internship programs are presented below (see Table 3). During the period from Spring 2002 - Spring 2004, 59 undergraduates and 51 graduate students participated in the internship program. Students were predominantly female in both programs (undergraduate $88.1 \%$ and graduate $80.4 \%$ ), aged $21-45$ (undergraduate $79.7 \%$ and graduate $82.4 \%)$, and close to graduation (61\% undergraduate were Seniors, and $67 \%$ graduate had completed $>18$ credits).
As of Summer 200448 agencies had been contacted (20 graduate, 23 undergraduate, 5 both); 58 internship positions had been developed (28 graduate and 30 undergraduate); 80 internships had been actualized (21 graduate and 59 undergraduate). Eleven positions were never filled (7 graduate, and 4 undergraduate). These sites range from organization serving the needs of former offenders to health maintenance organizations (see Table 4). As shown in Table 4 , the sites most frequently chosen were hospitals (30) categories, while the educational sites were least utilized (8).

Table 3

Sociodemographic Characteristics of Interns (2001 - 2004)

\begin{tabular}{|l|r|r|}
\hline \multicolumn{1}{|c|}{ Characteristic } & Undergraduate (n=59) & Graduate (n=51) \\
\hline Gender & & \\
\hline Female & $88.0 \%$ & $80.4 \%$ \\
\hline Male & $11.9 \%$ & $19.6 \%$ \\
\hline Age & & $0 \%$ \\
\hline $18-20$ years & $16.9 \%$ & $82.4 \%$ \\
\hline $21-45$ years & $79.7 \%$ & $17.6 \%$ \\
\hline$>45$ years & $3.4 \%$ & N/A \\
\hline Year in College & & N/A \\
\hline Underclassperson & $13.6 \%$ & N/A \\
\hline Junior & $25.4 \%$ & 33.3 \\
\hline Senior & $61.0 \%$ & $67.7 \%$ \\
\hline$\leq 18$ Graduate course credits & N/A & N/A \\
\hline$>18$ Graduate course credits & N/A & $27.5 \%$ \\
\hline Undergraduate health major & $96 \%$ & $72.5 \%$ \\
\hline MA Candidate & N/A & N/A \\
\hline MPH Candidate & & \\
\hline
\end{tabular}

Table 4

Community-Based Health Internship Partners

\begin{tabular}{|l|c|c|c|c|c|}
\hline & \multicolumn{5}{|c|}{ Community Health Activity } \\
\hline & $\begin{array}{c}\text { Assessment/ } \\
\text { Research }\end{array}$ & $\begin{array}{c}\text { Program } \\
\text { Planning \& } \\
\text { Implementation }\end{array}$ & $\begin{array}{c}\text { Program } \\
\text { Evaluation }\end{array}$ & $\begin{array}{c}\text { Direct } \\
\text { Service }\end{array}$ & Other \\
\hline Site Type & & & & & \\
\hline Hospital & 3 & 6 & 3 & 18 & \\
\hline Other health care settings & 1 & 1 & 3 & 8 & \\
\hline Other health-related agencies & 2 & 7 & 2 & 8 & 1 \\
\hline $\begin{array}{l}\text { Community-based } \\
\text { organizations }\end{array}$ & & 3 & 5 & 1 & \\
\hline Educational Institution & & & 1 & 7 & \\
\hline
\end{tabular}


A presentation of the 80 intern positions by category is also provided in Table 4. The students engaged in a wide range of potential career activities ranging from physical therapist to researcher. Four categories of intern activities were available to the students: direct service, program evaluation, program planning and implementation, and assessment/research. Direct service positions were the most utilized (52.5\%), while the assessment/research positions were the least utilized (7.5\%).
Program Implementation and Case Vignettes As anticipated, the CDM-guided development activities encountered multiple barriers (see Table 5). A description of the CDM steps, barriers encountered and the strategies used to master these barriers are presented below. Case vignettes have been provided to illustrate both the CDM step and the barrier encountered.

Table 5

CDM Steps and Barriers Encountered

\begin{tabular}{|c|c|c|c|c|c|c|c|c|c|}
\hline & CDM & $\mathbf{C D M}$ & $\mathbf{C D M}$ & $\mathbf{C D M}$ & $\mathbf{C D M}$ & $\mathbf{C D M}$ & $\mathbf{C D M}$ & $\mathbf{C D M}$ & $\mathbf{C D M}$ \\
$\mathbf{1}$ & $\mathbf{2}$ & $\mathbf{3}$ & $\mathbf{4}$ & $\mathbf{5}$ & $\mathbf{6}$ & $\mathbf{7}$ & $\mathbf{8}$ & $\mathbf{9}$ \\
\hline Barrier & & & & & & & & & \\
\hline $\begin{array}{l}\text { None } \\
\text { Organizational }\end{array}$ & & & & 0 & & & & & 0 \\
\hline $\begin{array}{l}\text { Community } \\
\text { Partners }\end{array}$ & 3 & & & & & & & & \\
\hline Individual & & & & & & & & & \\
\hline Students & & & & & & 2 & & 2 & \\
\hline Task Related & & & & & & & & & \\
\hline $\begin{array}{l}\text { Job } \\
\text { Description }\end{array}$ & & 1 & 2 & & & & & & \\
\hline Relationship & & & & & & & & & \\
\hline $\begin{array}{l}\text { Site Director- } \\
\text { Staff }\end{array}$ & & & & & 2 & & & & \\
\hline
\end{tabular}

$0=$ No barriers encountered; $1=$ Successful resolution; $2=$ Less than optimal resolution; $3=$ Unsuccessful resolution

Step 1: Establish a working group of co-change agents. The first step in the development process was to identify community partners who shared the goal articulated above and were willing to partner with a college. The FIDs sought potential sites through colleagues in the field, community-based organizations and health care agencies, and students already working in the health field. Once potential partners were identified, discussions regarding the mission, goals, and objectives of both the Internship Program and the partnering agency were initiated in order to assess the match. The primary barriers encountered during these efforts were organizational. The case vignette that follows describes an organizational barrier, agency bureaucracy, to developing a partnership with a local health care provider.

\section{Case Vignette \#1}

An undergraduate student expressed interest in interning within the Midwifery Department of a local hospital. The FID contacted the FS and expressed an interest in establishing a partnership. The FS, however, was not interested in serving as an undergraduate internship site. The FS explained that the policy of the Midwifery Department was to allow only graduate students in medicine or midwifery to interact with patients. Undergraduate students were assigned to clerical tasks only. Respecting the department's policies, attempts were made to negotiate assignments that would allow the undergraduate to observe the workings of the department. However, the FS was adamant and rejected a modified assignment. Thus, there was no basis for a partnership. 
Step 2: Recognize the problem and seek help. The target issue was conceptualized as the provision of meaningful work experiences to students, through the community - college partnership. Operationally, this step required agencies to provide a job description to each prospective intern. However, not every agency had predefined internship tasks and activities. The case vignette that follows describes a task related barrier, the absence of a job description.

\begin{abstract}
Case Vignette \#2
An undergraduate student expressed an interest in an evaluation internship at a health clinic. Contact with the director of the evaluation agency established a mutual interest in developing internship positions at the clinic. However, no existing job descriptions existed for such positions. A meeting was scheduled among the Evaluation Director, the FS, the FID, and the student at which all stakeholders expressed their expectations. As a result of this meeting, the FS developed a job description with clearly defined responsibilities including the tracking of client visits, analysis of attendance data, attendance at administrative meetings, development of health education brochures, and submission of a report at the conclusion of the internship
\end{abstract}

Step 3: Assess the Community. The college and the participating agencies exchanged detailed information regarding their respective needs and expectations. The FID presented the following expectations: a) overall supervision of the interns by a Master's level professional, b) job description reflective of a health professional in training, c) opportunity to complete required hours of supervised fieldwork. Additionally, the FID provided sites with relevant course materials, such as assignment sheets and course outlines.

The agencies, in turn, presented their expectations to the FID. While each agency expressed concerns consistent with their specific circumstances, general requirements included: a) dependability, accountability, and professional behavior from the students; and b) responsiveness and accountability from the FID in the event of problems, c) clear communication from the faculty, and d) students with the skills described in the job description.

At this point potential student-interns prepared resumes, letters of recommendation, and/or writing samples. FIDs initiated discussions with the students regarding the goals of the agency, including the target population, methods of operation, hours of operation, etc. The following vignette describes a task related barriers, the job description, that emerged.

\title{
Case Vignette \#3
}

A community-based organization contacted the graduate FID after learning of the internship program via word of mouth. The requirements for the agency's intern position included: a) proficiency in SPSS, b) background in public health/reproductive health, c) previous work experience in a fast paced office setting, d) demonstrated interest in reproductive health issues, and e) fluency in French and/or Spanish. Unfortunately, all students possessing these skills had already selected and been accepted by other agencies. Therefore, no match was possible at this community-based organization at this time. 
Step 4: Determine measurable goals. At this step, the co-change agents established the indices by which the success of the campaign would be evaluated. A student evaluation form was used as the initial measurement tool (see Appendix B). Outcomes included performance indicators such as attendance, rapport with staff, initiative and enthusiasm, attitude towards criticism, ability to use suggestions, ability to aid the agency, problem solving skills, responsibility, task completion, imagination and creativity.

Step 5: Plan diffusion activities. The CDM suggests that implementation plans should be flexible so that strategies can change based upon field events. The internship programs' major diffusion activity is to place the student into the fieldwork sites. The diffusion strategies of the undergraduate and graduate programs as follows:

The graduate program FID generates a list of placement opportunities. This resource explicates the intern's duties and the procedures for establishing contact. Typically, graduate students initiate contact, expressing interest in the placement opportunity and submitting a cover letter and resume. If the FS sees fit, s/he invites the student for an interview.

Alternatively, the undergraduate program requires each prospective student to select three agencies from the provided list and submit their choices to the FID. The FID forwards the student's name and resume to the SA. This initial contact is followed by a call from the student to the FS to schedule an interview. After the interview, the FID contacts the agency for feedback. Accepted students are contacted by the agency and the placement is initiated. Students who are not selected repeat the process with the second of their three choices. Barriers encountered in this step included a relationship issue among the staff or the site, as described in the following vignette.

\begin{abstract}
Case Vignette \#5
An undergraduate student applied for the position of Physical Therapy Intern with a local independent health care provider. This was a well-established site and the internship position was initiated to the satisfaction of all stakeholders. However, within a threeweek period the FS contacted the FID to say that the internship was in danger, through no fault of the student. The program's Physical Therapist had submitted her resignation due to issues between the therapist and the FS. Subsequently, the physical therapy program was discontinued. Attempts to negotiate a modified assignment for the student failed because only clerical tasks were available on the days that the student could attend the site. Therefore, this placement was no longer viable. Fortunately, a position was available with another independent physical therapy provider; the student was able to continue her internship at this alternative site within a week.
\end{abstract}

Step 6: Prepare communication tools. The objective at this step was to develop material explaining the available placement sites to prospective students, and to disseminate these tools via multiple media. The reality of competition for sites from other students in the program, as well as from students in other colleges, intensified the need for efficient communication to facilitate early application.
The undergraduate and graduate Internship Programs conduct dissemination activities through a combination of three channels. First, an internship description form lists the name, contact information, job description and hours of operation. This form is placed in an Internship folder available for student review in the FID office. A copy of this form can be found in Appendix C. Second, the site description forms 
are placed on line via BlackBoard, the college's on-line learning application. Third, outgoing student submit evaluations of their internship experience for review by incoming students. Thus, students can draw on both objective descriptions and subjective experiences in choosing a placement site.

In addition, the FID sends the Internship Program Guide to the FS. This form defines the roles and responsibilities of the agency staff and supervisor, the student, and the FS. Within this guide is an additional tool, which describes the intern's schedule at the site and confirms the availability of supervision. The FS and staff also disseminate communication tools describing the internship.

Increasingly, to formalize field arrangements, agencies and colleges require Affiliation Agreements (Kaplan, 2003; Oliva, 2003). These agreements are the functional equivalent of legal contracts, executed by counsel at both the college and the agency or health care organization. Unfortunately, mutually acceptable and properly executed agreements can take up to nine months to complete. The demand for Affiliation Agreements has led institutional barriers, as indicated in the following vignette.

\begin{abstract}
Case Vignette \#6
The FIDs first alert to the administrative requirement to formalize the field arrangements through Affiliation Agreements came from the field. In the Spring of 2002, two agencies requested executed Affiliation Agreements before any student placement could occur. One took a full year to execute. The FS stipulated that no students could be place until the completion of the affiliation process. Therefore, no intern could be placed in this site for the entire semester. The other agency offered an alternative: to consider the intern as a volunteer and place her through the volunteer department. This ad hoc remedy enabled the student to complete her field placement.
\end{abstract}

Step 7: Pretest. This step requires all tools, channels, and instruments to be field- tested prior to implementation. Due to practical limitations, (i.e., the internship status as a creditbearing course), no pretest was conducted. However, the FIDs have used the lessons learned from the initial Spring of 2002 cohort to improve the overall functioning of the program. The next vignette describes an interaction that has been seen over several semesters, i.e., how both staff and student behavior can create barriers to the internship placement process.

\title{
Case Vignette \#7
}

An undergraduate student expressed interest in an internship position in an adolescent sex-education program. The FID made the initial contact with the agency's FS and forwarded the student's resume. Approximately two weeks later, the FID received an email from the FS stating that the student had missed two scheduled interviews and would no longer be considered for the position. The FID immediately contacted the student to ascertain the reason for the missed appointments. The student provided a different account of the interaction. According to her, the staff person designated to conduct the interview had canceled the first interview. The student scheduled a second interview, but the staff person again called to reschedule. At this point, the student appeared lax in rescheduling the second interview, leading to a state of inertia. The FID convened a meeting with the student, during which the student's ambivalence regarding the internship became apparent. The student admitted to experiencing conflicting personal responsibilities. After some discussion of alternatives the student opted to drop the class. 
Step 8: Implement and monitor the plan. The $\mathrm{CDM}$ requires constant observation and feedback at each stage of the project. The FID's monitoring plan included periodic visits to each site. These visits provide an opportunity to identify barriers and facilitators to the internship. However, institutional and individual barriers rendered consistent site visits impossible. As a result of the high student to faculty ratio (approximately 15:1) in the Internship Program and other teaching, administrative, and research responsibilities, the FIDS were able to visit roughly $60 \%$ of their students in the field. This barrier is illustrated in the next vignette.

Step 9 Assess the final results. The final step of the CDM calls for an assessment of the agreed upon immediate, intermediate, and long term outcomes. The preliminary results can be found in Table 3.

\begin{abstract}
Case Vignette \# 8
In the Spring of 2004, one site visit was two months in the making for the graduate FID. A graduate student was engaged in health education and outreach activities at a new partner agency. The FS was enthusiastic about our burgeoning partnership, and was eager to have a face-to-face meeting to map out a plan for future internship opportunities. The FID and the FS scheduled a site visit by e-mail. The week leading up to the site visit turned tumultuous for the agency. Its central funding source was in jeopardy; closure became imminent. The agency rallied all its staff, volunteers, and partners (including this college) to write letters of support and to keep the office running. Painful downsizing, not closure, was the ultimate outcome of this crisis. When the agency regained its full service delivery, largely with volunteer staff, the FS invited the FID for a rescheduled site visit. This invitation came in the midst of other scheduled site visits, conference preparation, and the end-of-semester flurry for the FID. The FS and FID exchanged half a dozen e-mails before finding a mutually convenient date. The FID finally got to the site two months after the initially scheduled visit. Such a scheduling story is not uncommon.
\end{abstract}

\section{Discussion}

Developing an internship program in an urban college setting has highlighted the importance of establishing partnerships among the stakeholders and anticipating the emergence of multi-level barriers to successful implementation and maintenance. Each of these lessons is discussed below.

Establishing a partnership among the stakeholders. All of the multiple stakeholders involved in building a partnership are critical to the success of the program. Without agency sites there would be no internship. Likewise, without the college there would be no agency input into training. The CDM provides a framework for cultivating an enduring partnership among the stakeholders, founded on mutual trust and respect. The community intervention/research literature is full of examples of projects that were sabotaged by a basic distrust among the stakeholders (Baker, Homan, Schonhoff, Kreuter, 1999; Bowman, 1991). Examples of situations that could breed mistrust among stakeholders in the development of internship programs include: a) community partners viewing the college as inflexible and out of touch with community needs; b) college regulations regarding the credentials of the supervisor; and c) community partner and college unwillingness to modify pre-established procedures for intern. Field experience suggests that attempts to partner with institutions that adopt a take-it-or leave-it attitude toward the program usually end in failure. Likewise, it is unwise to think that potential community partners will react positively to similar methods from the college. 


\section{Anticipating and negotiating multi-level} barriers. Given the myriad potential interactions among stakeholders, it is not surprising that we encountered multiple barriers in the development process. The case vignettes illuminated select organization- related, individual- related, task-related barriers, and relationship-related barriers. It is important to note, however, that anticipation of these barriers does not translate to avoidance. Indeed, the multi-level, multi-layered barriers are the essence of any program that seeks to bring organizations together. Each barrier and its implications for program development is reviewed below.

Organizational barriers. Barriers such as policy or procedure that put the community partner and the college directly at odds are often difficult to overcome. Failure to effectively deal with such barriers often signals the end of a partnership before it even starts. As noted above, the current demand for Affiliation Agreements as part of the internship contract is a threat to the partnership. These agreements seek to limit the liability of an organization by specifying the terms of the internship and the limits of responsibility. However, a recent trend has been the adoption of a non-negotiable stance by both the community partners and the colleges. For example templates of the terms of the agreement may be are sent to the partner, with the warning that any change in the terms will result in the end of negotiations and, therefore, the partnership. Such positions have resulted in the premature termination of two internship sites over the past three years. Efforts to avert such terminations include ongoing communication between the FS and FID, who informs administrators at the community partners and college level of any event that might be problematic on an institutional level.

Individual barriers. As stated above, these are the barriers that are most anticipated by intern programs and for which the most strategies have been developed. Students are supervised on the site and participate in a weekly classroom seminar at the college. The FS and FIDs are on the alert for problems that the students are experiencing in the field. They are in contact several times during the semester to monitor the progress of the student and their own interactions. Students report their experiences in logs that both the FS and the FIDs review. Written and verbal communication by all stakeholders is frequent and open.

Task related barriers. Because of our proactive communication, task-related barriers have been kept to a minimum. Efforts to match student's interests and skills to placement site have led to a minimum of disruption in the internship experience, e.g., student requests for site transfers. The majority of students have expressed a positive learning experience during their internship, although the experience has led some students to reconsider their career path and explore new occupational choices. The FID and FS consider such a response a positive experience because it leads to a reevaluation and adjustment of the students' career choices. Likewise, no community partner has requested that an intern leave because of poor performance.

Relationship barriers. In the internship program as in life, relationship barriers are among the most difficult to overcome. Miscommunications regarding logistics and a mismatch of personalities have characterized some of the relationship-related barriers described above. Attempts are made to minimize these barriers between the student and the FS by requiring an interview prior to acceptance. Both parties have an opportunity to meet and assess the other and reflect on the working relationship. However, other dyads are more difficult to structure. As the relationships and fieldwork evolves, field supervisors and instructors must remain alert for problems that may arise.

\section{Summary and Recommendations}

This paper must be viewed in the context of certain limitations. First the examples of barriers experienced are by no means exhaustive. College faculty and community agencies or organizations interested in developing internships will encounter many other interesting barriers unique to their circumstances. Second, much of the data presented is anecdotal. A third year evaluation 
effort is currently underway to rigorously collect, analyze and report the Internship Program outcomes. Successful outcome markers will include retention of sites over a three-year period and number of job offers made to students, in addition to the previously mentioned indicators.

Nevertheless, drawing on the CDM and anticipating multi-dimensional barriers have provided a clear road map for the development of this internship program. Based upon these experiences, we propose the following recommendations to other internship program developers.

1. Colleges and organization administrators interested in developing internship programs are advised to embrace a fully collaborative approach in dealing with prospective partners. Establishing a partnership based upon equal status and mutual trust and respect are key ingredients to long lasting and effective partnerships.

2. Program and site directors charged with developing and maintaining internship programs should learn the needs of their potential partners and incorporate strategies these needs into the project. Additionally, directors are advised to anticipate and plan for all levels of the multiple level barriers outlined above.

3. Policy makers at the college and community partner level are urged to examine the impact of their procedures, such as take-itor-leave-it Affiliation Agreements, on the equal status partnerships that the program and site directors are attempting to develop. A willingness to negotiate with partners is essential to any community- based program.

\section{References}

Allegretto, S., \& Stettner, A. (2004). Educated, experiences, and out of work. Long-term joblessness continues to plague the unemployed. EPI issue Brief. Retrieved April 9, 2004, from http://www.epinet.org.content/cfm/isuebriefs ibs198

Anderson, P., Pulich, M., \& Sisak, J. (2002). A macro perspective on non-clinical student internship programs. Health Care Manager, 20, 59-68.

Baker, E. A., Homan, S., Schonhoff, R., \& Kreuter, M. (1999). Principles of practice for academic/ practice/ community research partnerships. American Journal of Preventive Medicine, 16, 86-93.

Bowman, P. J. (1991). Race, class and ethics in research: Belmont principles to functional relevance. In Black Psychology, Third Edition, pp. 747-766. CA: Cobb and Henry Publishers.

Coombs, D. W., Usdanm, S., Alexander, L., Averym J., Westfall, E., Pierce, T., \& White, C. (1998). A new teaching strategy to involve master's students in community health. American Journal of Health Studies, 14, 105-109.

Kaplan, R. (2003). Hold harmless agreements shift liability. Spotlight Online. June 27, 2003. Retrieved June 25, 2004, from http://new.naceweb.org/pubs/spotlight/s062703leg.htm

Meichenbaum, D., \& Turk, D. C. (1987). Facilitating Treatment Adherence: A practitioner's guidebook. New York: Plenum Press.

National Heart, Lung and Blood Institute (NHLBI). (1987). Executive summary - Strategies for diffusing health information to minority populations: Profile of a community-based diffusion model. US Department of Health and Human Services. Public Health Service. National Institute of Health.

O'Keeffe, A., Hibbert, K. (2003). Work experience: for whose benefit? New Statesmen, 132, 24.

Olivia, R. (7/1/2003). Personal communication.

Ryan, G., Toohey, S., \& Hughes, C. (1996). The purpose, value and structure of the practicum in higher education: A literature review. Higher Education, 31, 355-377.

Stokols, D. (1992). Establishing and maintaining healthy environments: toward a social ecology of health promotion. American Psychologist, 47, 6-22. 
Weston, R. E., Ray, K., Landers, C., Vaccaro, D., Futterman, R., Haley, N. J., \& Orlandi, M. A. (1992). Mobilization and educational strategies in a model community cholesterol education program. Health Values, the Journal of Health Behavior, Education and Promotions, 16, 8-21.

Weston, R. E., Rapkin, B, Potts, R. G., Smith, M. Y. (1998). The role of psycho-oncology in medically underserved communities. In Holland, J. (Ed.), Textbook of psycho-oncology: Psychological care of the patient with cancer. New York: Oxford University Press.

Author Information

R. Eric Weston, Ph.D.

Assistant Professor

Brooklyn College of the City University of New York

Department of Health and Nutrition Sciences

Ph. 718-951-5167

Rweston@Brooklyn.cuny.edu

Catherine D. Stayton, Dr. P.H., M.P.H.

Assistant Professor

Brooklyn College of the City University of New York

Department of Health and Nutrition Sciences

Ph. 718-951-5553

Cstayton@Brooklyn.cuny.edu 


\section{Appendix A}

\section{Community Partners of the HNTR at Brooklyn College*}

\begin{tabular}{|c|c|}
\hline Institution & Supervisors \\
\hline $\begin{array}{l}\text { Arthur Ashe Institute for } \\
\text { Urban Health }\end{array}$ & $\begin{array}{l}\text { Rosalind V. Wilson, MSW } \\
\text { Deputy Director for Programs } \\
\text { Necole Brown, MA } \\
\text { Deputy Director for Community Health Empowerment and External } \\
\text { Affairs } \\
\text { Richard Clare, BA } \\
\text { Project Coordinator } \\
\text { Marilyn White, MD } \\
\text { Program Director }\end{array}$ \\
\hline Cobble Hill Health Center & $\begin{array}{l}\text { Karen White } \\
\text { Director of Volunteer Services }\end{array}$ \\
\hline Coney Island Hospital & $\begin{array}{l}\text { Gail Erlich, BA } \\
\text { Director of Volunteer Services }\end{array}$ \\
\hline EVAXX, Inc & $\begin{array}{l}\text { John Cardwell, Ph.D. } \\
\text { President, EVAXX, Inc. }\end{array}$ \\
\hline $\begin{array}{l}\text { The Center for Law and } \\
\text { Social Justice at Medgar } \\
\text { Ever College }\end{array}$ & $\begin{array}{l}\text { Sam Anderson, Ph.D. } \\
\text { Educational Director } \\
\text { Caroline Roberts } \\
\text { Academy Director }\end{array}$ \\
\hline $\begin{array}{l}\text { Helping to End Eating } \\
\text { Disorders }\end{array}$ & $\begin{array}{l}\text { E. Fisher Turk } \\
\text { Founder of Photo Therapy } \\
\text { Ira M. Sacker, MD } \\
\text { Director HEED at Brookdale University Hospital and Medical Center }\end{array}$ \\
\hline Heritage Healthcare & $\begin{array}{l}\text { Stephanie Pinto } \\
\text { Executive Director }\end{array}$ \\
\hline $\begin{array}{l}\text { Hospital for Special } \\
\text { Surgery }\end{array}$ & $\begin{array}{l}\text { Chandler Wilson, MPA } \\
\text { Assistant Director of Patient and Public Education }\end{array}$ \\
\hline MetroPlus Health Plan & $\begin{array}{l}\text { Debra Corbett, M.S. } \\
\text { Senior Associate Executive Director, Quality Management } \\
\text { Cheryl Weston, RN, ACSW } \\
\text { Associate Director, Quality Management } \\
\text { Virgilina Gonzalez, MPH } \\
\text { Health Education Manager }\end{array}$ \\
\hline $\begin{array}{l}\text { Nazareth Regional High } \\
\text { School }\end{array}$ & $\begin{array}{l}\text { Peter Doran } \\
\text { Principal } \\
\text { Mr. Richard Dolan } \\
\text { Coordinator of the Physical Education Department }\end{array}$ \\
\hline
\end{tabular}




\begin{tabular}{|c|c|}
\hline Institution & Supervisors \\
\hline & $\begin{array}{l}\text { Harold Afiriyie, Ph.D } \\
\text { Michael Haskins } \\
\text { Robert Mistretta } \\
\text { Lydie Valvano }\end{array}$ \\
\hline $\begin{array}{l}\text { New York City Department } \\
\text { of Health and Mental } \\
\text { Hygiene Health Research } \\
\text { Training Program }\end{array}$ & $\begin{array}{l}\text { Regina Zimmerman, Ph.D, MPH } \\
\text { Assistant Commissioner, Bureau of Public Health Training }\end{array}$ \\
\hline $\begin{array}{l}\text { One-On-One Physical } \\
\text { Therapy }\end{array}$ & $\begin{array}{l}\text { Jessie Simons, MSBTT } \\
\text { Clinical Coordinator/Coordinator of Student Services } \\
\text { Joanne Zgomombic } \\
\text { Clinical Coordinator/Coordinator of Student Services } \\
\text { Giovanni Matera, MSPT, ATC/L } \\
\text { Michael Wright, ATC } \\
\text { Julio Flores, ACT } \\
\text { Richard Bodian, PT }\end{array}$ \\
\hline $\begin{array}{l}\text { Dr. Susan Smiths } \\
\text { McKinney Nursing \& } \\
\text { Rehabilitation Center }\end{array}$ & $\begin{array}{l}\text { Angela Cooper } \\
\text { Director, Volunteer Services }\end{array}$ \\
\hline $\begin{array}{l}\text { Teens Helping Each Other } \\
\text { Program } \\
\text { State University of New } \\
\text { York Downstate Medical } \\
\text { Center }\end{array}$ & $\begin{array}{l}\text { Christine Rucker, MA } \\
\text { Director, Adolescent Education Program } \\
\text { Marian Searchwell, BA } \\
\text { Program Coordinator }\end{array}$ \\
\hline $\begin{array}{l}\text { Center of Health Promotion } \\
\text { of Brooklyn College, } \\
\text { CUNY }\end{array}$ & $\begin{array}{l}\text { Patricia Antoniello, Ph.D. } \\
\text { Professor, Department of Health and Nutrition Science }\end{array}$ \\
\hline Brooklyn Alliance & $\begin{array}{l}\text { Valerie Andrew-Levich } \\
\text { Information Technology Specialist Teen Unit Coordinator }\end{array}$ \\
\hline Body Positive, Inc. & $\begin{array}{l}\text { Christopher Murphy } \\
\text { Director, Volunteer/Client Support Services }\end{array}$ \\
\hline
\end{tabular}




\section{Appendix B}

Student Evaluation Form

BROOKLYN COLLEGE - DEPARTMENT OF HEALTH AND NUTRITION SCIENCES

SUPERVISOR'S NAME

TITLE

AGENCY

PHONE

ADDRESS

NAME OF STUDENT INTERN

PART A - Please evaluate the student by checking the appropriate box.

\begin{tabular}{|l|l|l|l|l|l|}
\hline & $\begin{array}{c}\text { Unusually } \\
\text { superior }\end{array}$ & $\begin{array}{c}\text { Above } \\
\text { average }\end{array}$ & Average & $\begin{array}{c}\text { Below } \\
\text { Average }\end{array}$ & $\begin{array}{c}\text { No opportunity } \\
\text { to observe/ } \\
\text { does not apply }\end{array}$ \\
\hline 1. Attendance record & & & & & \\
\hline $\begin{array}{l}\text { 2. Rapport with } \\
\text { professional staff }\end{array}$ & & & & & \\
\hline $\begin{array}{l}\text { 3. Rapport with service } \\
\text { population }\end{array}$ & & & & & \\
\hline $\begin{array}{l}\text { 4. Initiative and } \\
\text { enthusiasm }\end{array}$ & & & & & \\
\hline $\begin{array}{l}\text { 5. Attitude towards } \\
\text { criticism }\end{array}$ & & & & & \\
\hline $\begin{array}{l}\text { 6. Ability to utilize } \\
\text { suggestions }\end{array}$ & & & & & \\
\hline $\begin{array}{l}\text { 7. Aids the function of } \\
\text { the agency }\end{array}$ & & & & & \\
\hline $\begin{array}{l}\text { 8. Perceives and } \\
\text { appropriately acts on } \\
\text { problem situations }\end{array}$ & & & & & \\
\hline $\begin{array}{l}\text { 9. Acceptance and } \\
\text { fulfillment of } \\
\text { responsibility }\end{array}$ & & & & & \\
\hline $\begin{array}{l}\text { 10. Ability to complete } \\
\text { work assigned }\end{array}$ & & & & & \\
\hline $\begin{array}{l}\text { 11. Imagination and } \\
\text { creativity }\end{array}$ & & & & & \\
\hline 12. Personal appearance & & & & & \\
\hline $\begin{array}{l}\text { 13. Potential to be an } \\
\text { effective worker in a }\end{array}$ & & & & & \\
\hline
\end{tabular}




\begin{tabular}{|c|c|c|c|c|c|}
\hline & $\begin{array}{l}\text { Unusually } \\
\text { superior }\end{array}$ & $\begin{array}{c}\text { Above } \\
\text { average }\end{array}$ & Average & $\begin{array}{c}\text { Below } \\
\text { Average }\end{array}$ & $\begin{array}{c}\text { No opportunity } \\
\text { to observe/ } \\
\text { does not apply }\end{array}$ \\
\hline \multicolumn{6}{|l|}{ setting similar to yours } \\
\hline FACTORS & $\begin{array}{l}\text { Unusually } \\
\text { superior }\end{array}$ & $\begin{array}{c}\text { Above } \\
\text { average }\end{array}$ & Average & $\begin{array}{c}\text { Below } \\
\text { Average }\end{array}$ & $\begin{array}{c}\text { No opportunity } \\
\text { to observe/does } \\
\text { not apply }\end{array}$ \\
\hline \multicolumn{6}{|l|}{ Work attitudes } \\
\hline \multicolumn{6}{|l|}{$\begin{array}{l}\text { 14. Accepts } \\
\text { responsibility }\end{array}$} \\
\hline \multicolumn{6}{|l|}{ 15. Takes initiative } \\
\hline \multicolumn{6}{|l|}{$\begin{array}{l}\text { 16. Follows policies, } \\
\text { rules, regulations of } \\
\text { agency }\end{array}$} \\
\hline \multicolumn{6}{|l|}{$\begin{array}{l}\text { 17. Accepts ideas and } \\
\text { suggestions of others }\end{array}$} \\
\hline \multicolumn{6}{|l|}{$\begin{array}{l}\text { 18. Performs tasks with } \\
\text { industry and drive }\end{array}$} \\
\hline \multicolumn{6}{|l|}{ 19. Other (please add): } \\
\hline \multicolumn{6}{|c|}{ Professional relationships with: } \\
\hline \multicolumn{6}{|l|}{ 20. Professional staff } \\
\hline \multicolumn{6}{|l|}{ 21. Support staff } \\
\hline \multicolumn{6}{|l|}{ 22. Supervisor } \\
\hline \multicolumn{6}{|l|}{$\begin{array}{l}\text { 23. Personnel from other } \\
\text { organizations }\end{array}$} \\
\hline \multicolumn{6}{|l|}{$\begin{array}{l}24 . \\
\text { Patients/clients/participa } \\
\text { nts }\end{array}$} \\
\hline \multicolumn{6}{|l|}{ 25. General public } \\
\hline \multicolumn{6}{|l|}{ 26. Other (please add): } \\
\hline \multicolumn{6}{|c|}{ Application of community health skills } \\
\hline $\begin{array}{l}\text { 27. Assessing health } \\
\text { problems }\end{array}$ & & & & & \\
\hline
\end{tabular}


R. E. Weston \& C. D. Stayton / Californian Journal of Health Promotion 2004, Volume 2, Issue 4, 1-19

\begin{tabular}{|l|l|l|l|l|l|}
\hline & $\begin{array}{c}\text { Unusually } \\
\text { superior }\end{array}$ & $\begin{array}{c}\text { Above } \\
\text { average }\end{array}$ & Average & $\begin{array}{c}\text { Below } \\
\text { Average }\end{array}$ & $\begin{array}{c}\text { No opportunity } \\
\text { to observe/ } \\
\text { does not apply }\end{array}$ \\
\hline $\begin{array}{l}\text { 28. Developing health } \\
\text { objectives }\end{array}$ & & & & & \\
\hline $\begin{array}{l}\text { 29. Planning health } \\
\text { programs and projects }\end{array}$ & & & & & \\
\hline $\begin{array}{l}\text { 30. Managing planned } \\
\text { programs }\end{array}$ & & & & & \\
\hline
\end{tabular}




\section{Appendix B Continued \\ BROOKLYN COLLEGE - DEPARTMENT OF HEALTH AND NUTRITION SCIENCES}

PART B - Please answer as completely as possible. Use a separate sheet if necessary.

1. Did the student show growth? If so, in what areas?

2. What are the outstanding strengths of the intern?

3. What are the areas needing improvement?

4. Other comments regarding the student intern:

5. What is your overall assessment of this student?

$\mathrm{A}=$ unquestionably superior; $\mathrm{B}=$ better than average; $\mathrm{C}=$ average; $\mathrm{D}=$ below average; $\mathrm{F}=$ decidedly inferior

THIS FORM, WHEN COMPLETED, SHOULD BE SENT DIRECTLY TO:

Raymond Weston. Ph. D.

Catherine Stayton, Dr. P.H., MPH

Brooklyn College

Department of Health and Nutrition Sciences

2900 Bedford Avenue

Brooklyn, NY 11210 USA

Or

Fax: 718-677-6189 


\section{Appendix C}

Site information dissemination tool

\section{Placement Site Description}

Name:

Address:

Telephone \#:

Contact Person:

Agency Description:

Position Title:

Position Description:

Operating Periods:

Requirements: 